scant attention to the architectural influence on the visual development of towns. Yet the appearance or "townscape" of a town is of vital importance today. Ewart Johns"s remarkable book British Townscapes (1965) is not listed in the bibliography. The urban scene of the older historic towns of Britain is changing rapidly and more studies of these towns are badly needed as part of the effort to maintain their character. It is well known that the Government is making such surveys of York, ('hester, King's Lym and Chichester to serve as models for future work and action.

E. W. Gillbert

\section{NUFFIELD PHYSICS}

\section{Nuffield Foundation Science Teaching Project}

Physics (quide to Experiments 2. Pp. xv +205. (London: Longmans, Green and Co., Ltd.; Harmondsworth. Middlesex: Penguin Books, Ltd., 1967.) 17s. 6d.

THIs volume commands the same admiration and poses the same questions as do others of this series. All aim to provide a fresh starting point, and they do this in a manner which has been recoived enthusiastically by able teachers and which has undoubtedly provided very great help and enlightenment for others. To start this operation at a sufficiently developed position has required the provision of large quantities of standardized equipment, and for the present this is linked with the requirement of a standardized treatment. However good of its kind this may be, and it is very good indeed, the value of the whole operation would be in doubt were this to become a static standard. The achievement of the initial presentation now has to be matched in what may prove a much more delicate operation.

J. (․ WILSON

\section{MAKING SCIENCE INTERESTING}

\section{Science Jackdaws}

No. I. Newton and Gravitation, by Colin Ronan; No. 2. The Discovery of the Galaxies, by Colin Ronan; No. 3, Pasteur and the Germ Theory, by J. K. Crellin. (London: Jonathan Cape, 1967.) All 12s. 6d.

A school or holiday visit to Hampton Court, Blenheim Palace. HMS Victory or the British Museum, with the attendant postcards and pamphlets, often stimulates considerable interest in Henry the Eighth, the Duke of Marlborough, Lord NeIson ind the ancient Greeks, and the events with which they were involved. The result may be avid reading of many books and the emergence of young experts on the reformation. military history or the Greck heroes. The initial stimulus to interest, which is presumably what schoolteachers always hope they are giving, is obviously very important for an understanding of people and events. When a visit is not possible a set of documents, pictures and broadsheets describing historical erents and famous lives would seem to be a good substitute. This is what Jackdaws provide, complete in a coloured folder, and now the long list dealing with historical events of social and political significance is joined by the first three concerned with science.

In each case the broadsheets provide the basic facts which are illustrated and supplemented by the other exhibits. Pasteur and the Germ Theory gives a comprehensive short biography and puts Pasteur's work in its historical context. There are charts showing the progress of the germ theory versus spontancous generation, and the development of vaccination and asepsis since Pasteur. Added interest is provided by reproductions of letters to and from patients, extracts from Pasteur's publications, a prescription for rabies and two contemporary pictures of the man.

An equally comprehensive account of one man's life and work, its background and implications, is provided by Neuton and Gravitation. Exhibits include extracts from Principia in manuscript (with a translation) drawings of Newton's optical apparatus, and two charts of the heavens. Such topics as the heavens are thoroughly explained in The Galaxies, which gives a clear account of the history of the study of astronomy and comes up to date as far as quasars and the rival theories of the origin of the universe. As well as charts and photographs of astronomers, their apparatus and their discoveries, the exhibits include a star chart for every day of the year which can be assembled easily.

Do it yourself is a feature of Science Jackdaws--there are instructions for constructing a simple ball rolling apparatus for examining Newton's principles and instruetions for growing mould and bacteria to test the germ theory. In each case there are questions to be answered when the documents have been studied, and a book list suggests further reading. But it may be only the keenest readers who reach this stage, for it requires some organization to reap full benefit from these outfits. Although the broadsheets form the backbone of the facts they do not provide comprehensive reference to the exhibits, so that the reader has to fit the exhibits into the story. This may stimulate thought, or it may mean that some children. particularly the younger ones to whom the format will appeal, do not get a full and coherent picture of the facts before them. A suggested schedule for studying the contents of the folder might be helpful. The publishers intend Jackdaws for children of secondary school age, and it is probably in schools that they can be most useful. Teachers using them to supplement textbooks would not encounter any problem with lack of co-ordination of facts. The charts and pictures would make a welcome adornment for classroom walls, or indeed for any walls.

The versatility of Jackdaws makes them more attractive than even the most lavishly illustrated book. and makes them more likely to arouse interest in their subjects. As a teaching aid or an introduction to potentially exciting topies which can be dull if dully presented Science Jackdaws look like a good buy. Darwin, Harvey, Faraday and the Wright brothers are promised in June and the publishers hope to widen their scope later to cover contemporary scientific topics.

MARY liNDLEY

\section{RESEARCH IN INDUSTRY}

\section{Industrial Research in Britain}

Sixth edition. (Advisory editor: I. D. L. Ball.) Pp. 923. (London: Harrap Research Publications, 1968.) 168s. net.

$\mathrm{IT}_{\mathrm{T}}$ is good news that Industrial Research in Britain, a somewhat irregular publication, has now appeared in a sixth edition. At the time of the fifth edition, the publishers declared their hope of publishing new editions overy other year, but have failed to live up to it. As a result, the last edition, now almost four years old, was rapidly becoming useless. The sixth edition is larger, more expensive, but just as valuable as tho last. Almost alone among comprehensive reference books, Industrial Research in Britain is still small enough to be manageable, and convenience counts for a lot.

The largest part of the book is concerned with research work in industry. Although some companies are still difficult about supplying information-and some expressly ask to be excluded-the list is extensive. In each case the director of research, his senior colleagues, and the information officer are listed by name, and a brief description of the work is given. There is also a complete list of the research establishments of the Ministry of Technology and the other ministries, and details of research associations. The university section repeats in a less convenient form much of the material in the volumes on Scientific Research 